\title{
Agentive Apprenticeship of Observation and English Teacher Identity: A Pakistani Case of Learning to Teach English
}

\author{
Liaquat Ali Channa \\ Balochistan University of Information Technology, Engineering \& Management \\ Sciences (BUITEMS)
}

\begin{abstract}
An exploration of literature on second/foreign language (L2/FL) teaching suggests that the phenomenon in question has been investigated either by examining classroom processes or by exploring teachers' lived experiences. Situated in the latter area, this paper reports a qualitative study that understands how Pakistani primary school teachers learn to teach English - the subject mandated in recent curricular reforms - and develop their English teacher identity. The findings problematize the apprenticeship of observation concept and demonstrate that the teachers agentively draw upon their favorite English learning experiences. They teach English not the way they were taught, rather, they teach the way they loved learning English. Thus, they develop the English teacher identities they adored while they were students. The paper presents pertinent implications.
\end{abstract}

\section{Resumé}

Une exploration des écrits scientifiques sur l'enseignement des langues secondes/étrangères $(\mathrm{L}+)$ suggère que le phénomène en question a été étudié soit en examinant les processus de classe, soit en explorant les expériences vécues par les enseignants. En adoptant la dernière approche, le présent article rend compte d'une étude qualitative qui examine comment les enseignants du primaire pakistanais apprennent à enseigner l'anglais - la matière prescrite dans les récentes réformes des programmes - et développent leur identité de professeur d'anglais. Les conclusions problématisent le concept d'apprentissage d'observation et montrent que les enseignants s'inspirent de leurs expériences d'apprentissage de l'anglais préférées. Ils n'enseignent pas l'anglais comme ils l'ont appris, mais plutôt comme ils ont aimé l'apprendre. Ainsi, ils développent les identités des professeurs d'anglais qu'ils adoraient lorsqu'ils étaient élèves. L'article présente des implications pertinentes. 


\section{Agentive Apprenticeship of Observation and English Teacher Identity: A Pakistani Case of Learning to each English}

Reviewing scholarship on second/foreign language (L2/FL) teaching suggests that how a teacher teaches English as an L2/FL has been examined at broad two levels. First, how a teacher teaches English as an L2/FL has been studied at the language classroom

level. This line of inquiry has examined English language teaching techniques and methods, teachers' and students' interactions, students' behavior with respect to their anxiety, motivation, and willingness to speak, and assessment and error treatment in the classroom (Allwright \& Bailey, 1994; Chaudron, 1988; Larsen-Freeman, 2000; Lier, 1988; Markee, 2000; Richards \& Rodgers, 2001; Schachter \& Gass, 1996). Second, how a teacher teaches English as an L2/FL has been investigated in the context of how a teacher has, in effect, learned to teach English. This professional development strand of research has looked into how teachers have learned to teach, and what sources have taught a teacher to teach English as an L2/FL in a certain way (Bullock, 2011; Johnson, 2006; 2009; Lantolf \& Poehner, 2008; Lantolf \& Thorne, 2007; Smagorinsky \& Barnes, 2014).

The first line of inquiry has focused upon events, processes, and individual differences of a target language classroom. The second strand of research, however, has explored teachers' lived experiences of teaching a target language. Unlike former research that has been informed by psycholinguistic, sociolinguistic, and social theories of language learning and teaching, the latter area of knowledge has drawn upon various psychological and sociocultural theories of human development. While target language students and their language development have largely been in the limelight in the first line of inquiry, target language teachers and their professional development, have been the common interest in the second strand of inquiry (Bashiruddin, 2003; Westrick \& Morris, 2016).

Lortie's (1975) theory of apprenticeship of observation has been a dominant analytical framework in the second strand of inquiry for understanding how teachers learn to teach. Lortie's theory holds that teachers teach the way they were taught. This theory is rooted in the transmission model of learning and considers teachers as passive receivers. Whether teachers really teach the way they were taught or teachers agentively learn to teach by consciously drawing upon their favorite learning experiences has not largely been investigated. Thus, this phenomenon needs an inquiry. Additionally, how this learning to teach impacts construction and negotiations of teacher identities also needs an examination. Within this scope, this study was conducted to answer the following two research questions:

1. How do lived experiences of learning English facilitate Pakistani primary teachers to learn to teach English in primary schools?

2. How do Pakistani primary teachers negotiate and construct their English teacher identities in the process of learning to teach English?

The purpose of this study was to understand how Pakistani government primary school teachers - the teachers who teach in Grades 1 to 5 - learn to teach English. English has recently been implemented as a compulsory subject in Grade 1 onwards in the government schools of Pakistan (Channa, 2014; 2015; 2017). This study, in particular, investigated the role of lived experiences for learning to teach in order to understand the dynamics that informed Pakistani teachers' English language teaching practices and 
identity negotiation. Moreover, the purpose of this study was also inspired by Moodie (2016) who argued that while how teachers learn to teach has been studied in the western contexts where English is the first or native language, "there is a need for further research, particularly regarding the beliefs and practices of public school teachers in English as a foreign language (EFL) contexts that have undergone curricular reform" (p. 29-30). Like Moodie (2016), this study did not directly examine the impact of teacher education on the participants' learning to teach. Thus, Moodie's (2016) suggestion served in this study as a road map in terms of understanding how teachers' lived experiences facilitated the teachers to learn to teach English in EFL contexts such as Pakistan. Against this scope, this study aimed to contribute in filling the underscored gap.

\section{English and its curricular reforms in Pakistan}

Pakistan was established on August $14^{\text {th }}, 1947$. The then policymakers took English — the official language of the Sub-continent — as the default official language of this country. The constitution of the Islamic Republic of Pakistan (1973), the current legal framework, continued using English by declaring it as the official language. However, the constitution designated Urdu as the national language. The Supreme Court of Pakistan has recently nominated Urdu as the official as well as the national language of Pakistan (Haider, 2015). Thus, these two languages - English and Urdu - became the languages of power in this country (Channa, 2014; 2015; 2017; Rahman, 1996; 2002).

Despite the fact that English is a foreign language, it is the key and the most important language. It holds a significant place in every social sector of this country including the public educational system (Mahboob, 2002; Mansoor, 2004). In education, for instance, the latest National Education Policy (2009) has recommended teaching English as a compulsory subject from Grade 1 onward. The policy has also mandated all the provinces to employ English as the medium of instruction for content subjects in Grade 4 and onwards in the future (Channa \& Manan, 2015). English is already employed as a medium of instruction in Grade 11 and Grade 12. Moreover, English becomes the sole medium of instruction in all public and private Pakistani university systems. Since English is at the top hierarchal position in Pakistan, those who are not fluent in the language are unable to socially advance, become employed, and compete in various competitive exams. English, thus, occupies the most critical and central place in a Pakistani students' life (Manan, David, \& Dumanig, 2016).

Interestingly, government Urdu/Sindhi medium public schools (GU/SMPS) are the only places for low socio-economic background students to learn English. Expensive private English-medium schools, colleges, universities, and after-school tutoring systems, however, serve this purpose for the elite of this country. Whether these low socio-economic background Pakistani students are able to learn English and master it, compete with other students, including the ones who graduate from the expensive English medium institutes, and successfully become employed, depends largely upon how government teachers of the schools teach English to them (Cole, 2010; Panezai \& Channa, 2017; Channa \& Panezai, 2019). They determine the future of the majority of Pakistani students. But, how the teachers, who have been entrusted with the responsibility of teaching English as a compulsory subject themselves, learn to teach English remains underexplored in the Pakistani context. This study was conducted in this backdrop to see how they have been learning to teach the newly introduced subject in their public schools of Pakistan. 


\section{Theoretical underpinnings}

Lortie (1975) in Schoolteacher: A sociological study used the concept of apprenticeship of observation to account for the influence of the previous experiences of being schoolchildren on the teachers' learning to teach. Borg (2004) explained the concept as "the phenomenon whereby student teachers arrive for their training courses having spent thousands of hours as schoolchildren observing and evaluating professionals in action" ( $p$. 274). The concept of the apprenticeship of observation suggested that teachers learned to teach by drawing upon their experiences about how they were taught when they were schoolchildren. In other words, teachers' previous experiences of being schoolchildren taught and guided them to teach.

Lortie (1975) held that the apprenticeship of observation was powerful enough to downplay the role of pre and in-service teacher education. He thought the apprenticeship of observation had limitations in the sense that the apprenticeship period developed and showed to the schoolchildren - who are now teachers - a partial view of teaching. He stated that the schoolchildren saw their teachers only at "front stage and center like an audience viewing a play"; they did not see their teachers at the "backstage" (p. 62). Lortie argued:

Students do not receive invitations to watch the teacher's performance from the wings; they are not privy to the teacher's private intentions and personal reflections on classroom events. Students rarely participate in selecting goals, making preparations, or post-mortem analyses. Thus, they are not pressed to place the teacher's actions in a pedagogically oriented framework (p. 62).

Lortie (1975) suggested that while the schoolchildren saw how their teachers conducted teaching, they did not see how the teachers planned to teach and achieved their goals. The schoolchildren saw their teachers from "their specific vantage point" of being students (p. 62). Thus, they developed their own perspectives about teaching and later learn(ed) to teach by drawing upon the partial views of teaching that they had developed and solidified during the apprenticeship of observation period while they were students.

Darling-Hammond (2006) agreed with Lortie (1975) and believed that teaching was a complex activity. She stated that there were two other problems in addition to the apprenticeship of observation that hindered teachers learning to teach: (1) "the problem of enactment" (i.e., thinking and acting like teachers), and (2) "the problem of complexity," (i.e., understanding that teaching is a highly complex activity and responding accordingly) (p. 35). Mewborn and Tyminski (2006) and Smagorinsky and Barnes (2014) echoed the same as Darling-Hammond (2006). However, these scholars held that the conception of apprenticeship of observation needed reexamination because it was conservative and rooted in the transmission model. The model assumed that teachers transmit thoughtlessly and linearly whatever they were taught when they were students. The transmission concept took teachers as docile beings who did not exercise their agency for adjusting their teaching as per their situations. Additionally, the concept only alluded to the negative teaching models, whereas, these scholars argued, there could be a positive/progressive apprenticeship of observation that teachers could agentively draw upon while they teach.

In addition, taking into consideration the debates about how humans learn to teach from a sociocultural perspective, it has been argued that teachers are active and agentive. 
They learn to teach by creatively appropriating their previous experiences of learning (English) as mediational means for their teaching (Johnson, 2006; 2009; Lantolf \& Poehner, 2008; Lantolf \& Thorne, 2007; Vygotsky, 1987; 1978; Wertsch, 1985). Wertsch (1985) held that mediational means can both be psychological as well as physical resources. Both tend to be social in their origin. Mediational means not only provide an impetus to a human mind but also help humans to self-regulate themselves by appropriating the means needed in order to accomplish successfully an activity. Therefore, scholars such as Boyd, Gorham, Justice, and Anderson (2013), Bullock (2011), and Greenwalt (2014) believed that the core objective of effective teacher education should be to take teachers as sociocultural and agentive beings and help them to learn to deal with the problems that DarlingHammond (2006) discussed.

Unlike Lortie's view regarding the apprenticeship of observation that it is limiting and only damaging, this study is guided by the sociocultural theory about learning to teach and contends that the apprenticeship of observation is conceptualized partially. It overlooks the agentive aspect of a human that lends to them an ability to consciously act. This study holds that teachers can be agentive and the apprenticeship of observation could be a progressive meditational means that can have the potential to teach teachers how to teach in a progressive way.

\section{Study}

This study situated itself in an interpretative epistemological viewpoint because it aimed at qualitatively understanding Pakistani government primary school teachers' lived experiences of learning to teach (Johnson, 2009). Specifically, the study intended to explore the impact of their English learning experiences on their learning to teach English. The researcher employed a case study design from qualitative research to meet this purpose (Yin, 2013). The researcher took government primary school teachers - the teachers who teach Grades 1 to 5 - from the rural upper Sindh province of Pakistan as the case. Taking teachers as the case helped the researcher to understand their lived experiences regarding how they implemented the recent English as a compulsory subject policy in their respective rural schools.

The researcher used a networking sampling strategy to select his participants. He used Skype because it was inconvenient to access rural teachers while working on this project in an area away from the teachers. It was culturally difficult for the male researcher to talk to a female teacher via Skype in the rural areas of the Sindh province. He, therefore, purposefully requested only male primary school teachers to participate in the study. Table 1 shows the teachers and their background characteristics who participated in the study. 
Table 1

Participants in the study

\begin{tabular}{ccccc}
\hline Name & Age & $\begin{array}{c}\text { Grade } \\
\text { taught }\end{array}$ & Experience & Education \\
\hline Nazakat & 35 & 4 & 9 Years & $\begin{array}{c}\text { Master of Arts (M.A.)+ Primary } \\
\text { Teaching Certificate (PTC) }+ \\
\text { Certificate in Teaching (CT) }\end{array}$ \\
Hadi & 38 & 3 & 12 Years & $\begin{array}{c}\text { Master of Arts (M.A.)+ Primary } \\
\text { Teaching Certificate (PTC) }+ \\
\text { Certificate in Teaching (CT) }\end{array}$ \\
& & & & $\begin{array}{c}\text { Master of Arts (M.A.) + Primary } \\
\text { Zamman }\end{array}$ \\
& 40 & 5 & 13 Years & $\begin{array}{c}\text { Teaching Certificate (PTC) }+ \\
\text { Certificate in Teaching (CT) }\end{array}$
\end{tabular}

The first participant - Nazakat (pseudonym) — played the role of a gatekeeper and introduced to the researcher two other teachers - Hadi and Zamman (pseudonyms) — who also agreed to join the study. The participants' ages ranged from 35 to 40 years. All of them had Master of Arts degrees - 16 years of education - along with professional certifications such as a Primary Teaching Certificate (PTC) and Certificate in Teaching (CT). The participants had teaching experience ranging from 9 to 13 years. They all taught English as a compulsory subject through the use of official English textbooks at various primary grade levels at the time of interviewing.

The participants were interviewed in a semi-structured manner (Roulston, 2010). For data triangulation, they were also asked to maintain their journal writing for 3 months. They were asked to write their journals as guided by Knapp (2012) and Thorpe (2014). They were instructed to write in their journals using any language with which they felt comfortable. They were guided to write what they taught and how they taught the English subject to their classes. The teachers wrote their journals in the Sindhi language. The interviews helped the researcher to gain a better understanding about the teachers' dynamics of learning to teach (Cohen, Manion, and Morrison, 2007). Moreover, the journal writing by the participants provided to the researcher with inclusive snapshots of how they, in effect, conducted the activity of teaching English to their students (Knapp, 2012; Thorpe, 2014). The interviews were conducted in the participants' native language-Sindhiaccording to the time and place suitable to the participants. The researcher collected a total of three approximately one-hour long interviews and three journals.

It must be mentioned here that the period system did not exist in government primary schools where the teachers taught when the study was conducted. The period system refers to the systemic teaching of subjects by their specialist teachers for a period of 40 to 50 minutes a school day. For instance, under the period system, someone who has an undergraduate or a graduate degree in mathematics teaches the subject of mathematics under the specified time. Similarly, someone who has an undergraduate or a graduate degree in English teaches the subject of English under the listed period. This period system 
is prevalent in Pakistan in either government higher secondary schools where education is given from Grades 6 to 12 or in government colleges that deal with Grades 11 and 12.

In government primary schools that instruct Grade 1 to 5 , a single teacher in a certain grade level, however, is supposed to teach all the subjects to his/her students. The teacher turns out to not only be the class teacher but also the teacher of all subjects. Thus, it is up to the primary school teacher to teach a certain subject at a certain time for a certain period during a school day. Due to the overcrowded nature of classes and the absence of a period system, the participants of this study were unable to teach every subject on a daily basis. Thus, the participants of this study taught English and wrote in their diaries as per their convenience. For instance, when they were asked if they wrote in their diaries whenever they taught English, they replied they did not because they believed if they taught a lesson in a series of classes, they only wrote about one class. In sum, Zamman's journal had 18 entries, Hadi's journal 15, and Nazakat's 8 entries.

After the researcher interviewed the participants, he applied the strategy of transcribing and translating the data by following the suggestions that Halai (2007) has offered for interviews that are in a language other than English. Keeping in view research ethics, the researcher changed the names and other participants' personal information. $\mathrm{He}$ also shared transcripts with the participants to double-check the content. He used the member check strategy for establishing the trustworthiness of the research data as well as the research process (Nowell, Norris, White, and Moules, 2017; Shenton, 2004). He analyzed the transcriptions and journal entries by following the procedure of thematic analysis as suggested by Braun and Clarke (2006).

Braun and Clarke (2006) have mentioned six steps for conducting a thematic analysis. In the first step, the researcher read data several times to acquaint with them. In the second step, he produced initial codes by underlining data and writing main words on the side of each page of transcription. In the third step, he found out themes from the initial codes. These themes were then examined in the fourth step. In the fifth step, the themes were re-written through the participants' voices/words. The sixth step included the section of findings. All these steps were meticulously followed with both the types of data: journal entries and interview transcripts.

\section{Findings}

The following are the themes that the researcher found through the thematic analysis of the data.

\section{"The teacher of my class of sixth grade is the one I still remember a lot."}

This theme relates to the role of the participants' favorite teachers as mediational means who guided them to conduct their activity of teaching English and construct and negotiate their identities as English teachers. Hadi - the Grade 3 teacher - uttered the above words when he recounted his English language teaching experiences. These favorite teachers appeared to the participants as good teaching models. For instance, discussing teaching qualities of two of his teachers — Sir Sarmad and Sir Ahmed — who Hadi appreciated the most when he was in high school, he said: 
They [Sir Sarmad and Sir Ahmed] taught us very well how we should read our English lesson. They gave us a proper time and explained lessons very well. They also spoke English and compelled us to speak English. They used to create opportunities in class and students had to have dialogues and conversations in English. Due to these things, I liked them. Other teachers did not teach as they did. Other teachers simply asked us to read; they did not explain the lessons very well. These two teachers were different from others in the sense they used to create amusement in their teaching style. In addition, they used to create fun in the class by arranging word games and spelling contests. Whatever they taught made sense to us. Other teachers did not teach this way. These teachers had their own unique style.

Hadi recounted that unlike his other teachers, Sir Sarmad and Sir Ahmed were not only self-motivated English language teachers but they also taught English in a matchless style. These teachers were characterized by qualities such as that they were opportunity providers for English speaking, facilitators in various target language learning tasks, actors in that they spoke English in a high performing manner, and good explainers of the target language content. Hadi also identified Sir Lal Bux - the teacher who taught to him English when he was in Grade 11 - being an English teacher of such qualities.

This pattern of liking English teachers appeared in the data of other participants too such as Nazakat and Zamman. For instance, Zamman - the Grade 5 teacher - also remembered his teachers that he viewed as good teaching models. Recounting the teacher who taught to him English in Grade 6, Zamman said:

The teacher who taught us English- he was our class teacher too-was a great English teacher. Sir Sarwar was his name. I liked his teaching a lot. He was the best teacher I have ever had. I think he was the best of the best teacher. Other teachers have also taught to me English. They did not teach the way Sir did. But, when I entered in Grade 7, Sir Nisar Khan was our English teacher.....hehehhe.....he rather pushed us back than helped us to advance. He did not teach at all. The situation of our class more worsened when Sir Marghoob taught us English in Grade 8...hehehhehe...you know....

Zamman consciously differentiates between those teachers who taught English in a good manner and those who did not. Zamman takes Sir Sarwar as his most favorite English teacher in terms of his way of teaching. When the researcher probed Zamman further about Sir Sarwar, he learned that Sir Sarwar had the matching identity traits that Hadi related to Sir Sarmad, Sir Ahmed, and Sir Lal Bux: active, dynamic, engaging students in his teaching, helpful, and encouraging.

Taking into account the identity traits of the English teachers the participants adored, these participants attempted to exhibit the same characteristics by their identity as being English language teachers. They wanted to become the identical English language teachers they idolized and cherished. For instance, below is a snapshot from Hadi's journal that shows how he teaches English: 
Today, I taught the first unit of the English textbook. The title of the unit was "After the holidays (Conversations/Greetings)....I noticed that students were taking interest in the English subject. I asked them to open the first unit on their textbooks. I asked my students what they saw in the unit, what the pictures of the unit suggested to them, and, overall, what the unit (lesson) was about. Almost all of my students raised their hands and were ready to guess what the lesson was about. The main purpose of raising these questions was to involve my students in the reading process and checking if they could guess the lesson before reading it. These prereading questions help a lot in comprehending a lesson. Actually, I have observed that the more you involve students the more they take interest. After I asked a few students randomly what the unit was about, I thought to create fun by making four pairs of students as the pairs could role-play the dialogues. I was trying to teach this lesson with the help of an activity. But, before that, I asked all of my students to listen to me carefully. I read aloud the lesson-dialogues - twice. I acted exactly how the dialogues demanded. All the students enjoyed and listened to me carefully. Later, I created four pairs and called each pair and role-play the dialogues. Not only the pairs enjoyed but the other students too who saw them acting enjoyed. It was a great fun.

The snapshot shows that Hadi is trying to teach English in an engaging way. $\mathrm{He}$ clearly knows that teaching becomes a one-man show if students are not involved. Resultantly, teaching becomes boring and linear process. He knows that his students take an interest in learning English and consciously takes measures to engage his students by capitalizing on their interest. Not only does he want his students learn English but the excerpt shows he also wants his students learn English in a way that creates fun through activity and role-playing. Nazakat's — the Grade 4 teacher - journal also presents such pedagogical examples. For instance, he described in his journal how he taught an English lesson by following his beloved teachers:

....I asked my students whether they knew about group discussion, work, or competitions. These students did not know about these things. I taught to them how we can do group work. The first lesson of the English textbook of Grade 4 consists of a lunch dialogue amongst three members of a family. I took three students out from class. As is in the lesson that there are two girls and one boy, I also took two girls and one boy out from the class. I assigned them the characters and asked them to assume they were the same family and role-play. They first repeated on their own. Later, they role-played the dialogues and had an exact conversation. Although it was very difficult for the children to first do so, they learned to do well after a passage of time. All the students enjoyed and understood well these dialogues. These students shared with me that they enjoyed a lot speaking in English in this way.

This snapshot demonstrates that Nazakat is also trying to involve his students. He wants to create excitement in his teaching by engaging students in a role-playing activity. He chooses students as per the requirements of the lesson. The male and female students perform/read the lesson. Thus, he conducts such dialogue sessions as all could read the 
lesson and get involved. The result of involving students is also clear in the excerpt that the students enjoyed learning English through the activity.

One may argue that the participants' way of teaching English, i.e., enacting their identity as an English language teacher, is dialectically formed and negotiated by the English teachers - the mediational means - the participants liked (Vygotsky, 1934/1987; 1978). The journal data demonstrated that the participants tried to enact similar identity of an English teacher in their English teaching practices that they adored. They wanted to be fun, be engaging, involve students, and to provide opportunities to practice English. In sum, the participants' favorite English teachers played a mediational role in helping them to learn to teach and dynamically form and enact their identity of English language teachers (Lantolf \& Thorne, 2007; Lantolf \& Poehner, 2008; Wertsch, 1985).

\section{"If the basics of any child are built well, s/he would not suffer."}

This theme relates to a focus upon developing the basics of English in early grades among students, and their dynamic relation with the way the participants were taught English by their favorite teachers. Zamman uttered the above-quoted words when he shared his views about how the primary school students might be saved from future suffering in their higher grades by focusing upon the basics of English in earlier grades. He stated:

Actually, the real problem of learning English is basics. If a child is taught the basics of English very well, s/he will definitely build upon it in his/her later grades. But, if s/he is not taught the basics very well, s/he will suffer in the future. A majority of our children cannot and do not learn English because they do not have strong basics. If the basics of any child are built well, s/he will not suffer ahead.

Zamman believed that developing the basics of English in early grades is highly crucial. He held that the majority of the students suffered because the basics of English were not built solidly in their early grades. Thus, they suffered in the form of not being able to successfully learn English in their later grades. A similar focus upon the basics of English was also evident in the other participants' experiences of teaching English. For example, answering a question about detailing in sequence how typically he taught English — that shows how he focused upon the basics — Nazakat replied:

Actually, in the beginning of the class, I start with English conversation with these children - the basic conversation such as what is your name?, etc. Later, I check students' homework. I check their copies one by one. Subsequent to that, I ask them to read to me their lesson - the lesson from their English textbooks. I only want to teach to them some basics of English. For example, I teach to them $\mathrm{ABC}$, basic vocabulary such as the English names of the seasons, days, colors, and the spellings of the months of a year. In the English conversation, I more focus upon basic questions such as "What is your name?", "What is your father's name?", etc. This is how I teach English in the school. 
The above words suggest that Nazakat focusses upon building the basics of English by asking basic questions and teaching basic vocabulary. Exploring if the way the participants focused upon the basics of English in earlier grades had any dynamic relation with the way they had been taught English when they were students, data suggested that it was related. For instance, while discussing his teaching of the basics of English, Nazakat held that "this was the stuff we routinely did when we learned English." Moreover, recounting how Sir Sarwar taught English to Zamman when he first started learning English, Zamman viewed:

He taught us how to read, he taught us vocabulary, pronunciation, and use of words. In addition, his pronunciation was very good and charming....he would first take our attendance. Then lesson-reading started. We all one by one would read to him the lesson in the class. Not only he but we also all listened to the lessons. In addition, he would ask us the meaning of the specific words from the lesson...... When he would give us lesson, he used to tell the meaning of the words, pronunciation of the words, and synonyms of the words. After we finished our lesson, he used to dictate us different words. After dictation, he would check our copies. Thus, those students who made mistakes in spellings, he would write the words on three liner copies and ask them to write the whole page at home. On the other day, he would check this homework.

This account of the way Zamman was first taught English resonated with the way he conducted his activity of English teaching mentioned in his journal. They both focused upon developing the essentials of English. A passage from Zamman's journal demonstrates his concentration on developing fundamentals of English:

Before I asked my students to read their lessons to me, I first read the lesson alone and then asked them to read loudly after me line by line. My purpose of doing was to develop their pronunciation - the basics of learning English. If they did not know the pronunciation of the words, they would not be able to read lesson correctly and fluently. Only after doing this, I then asked all my students to read their lesson to me loudly. I ordered all the other students to listen to the reader carefully as I might ask them spellings of words, their meaning, and other basic things.

Zamman's journal excerpt shows that he too is concerned about developing the basics of reading English. This pattern of focus on basics was also evident in Hadi's language learning and teaching experiences. Replying how Hadi fist started learning English from Sir Sarmad, Hadi said:

I remember English as a compulsory subject started in Grade 6. I also remember when the teacher asked us to bring a three-liner copy for English writing. I got very happy that I was going to learn English then. I remember that the teacher spent about half a year on teaching us the capital and smaller $\mathrm{ABCs}$ on the three liner copies. After the six months, the teacher started textbook and then we used to read lessons from the book. The teacher focused upon teaching basics of English such as vocabulary, conversation, 
pronunciation, etc. So, it started like this that we started learning English from the class of Grade 6.

Hadi recounts the basics of English that his teacher taught to him when he learned English. He shows that his teacher focused on developing the fundamentals of English such as vocabulary, conversation, pronunciation, etc. How he concentrated upon the basics in his teaching of English, a piece from journal reads:

After I read a lesson loudly to my students, I asked them to write the lesson on their three liner copies in beautiful handwriting. I told them that their writing should be clean and neat. I did this to develop their basics of writing English correctly and beautifully. If they would not develop their English writing, they would suffer in exams where writing English accurately and attractively matters a lot. As they wrote, I started writing the difficult words, their pronunciation, and meanings in Sindhi on the board. After they were done with writing lessons, I asked them to note down what was written on the board. I gave them homework to remember the spellings of words and meanings because dictation would be conducted in the next class. These are the basics that are highly important for them to learn English.

Hadi's journal snapshot demonstrates that he too is concerned with developing the basics of English - the basics that would help his students to write well and succeed. From these instances, it appears that the participants' English language learning experiences dynamically formed their ideas, such as the basics of English, and taught them how to teach English. These ideas - mediational means - later mediated their activity by helping them to self-regulate and conduct the activity of teaching English and developing their identity (Johnson, 2006; 2009; Wertsch, 1985). It appears that the participants' focus upon this concept of the basics in their language teaching could have originated from their English learning experiences (Johnson, 2006; 2009). The way they were taught English could have dynamically impacted their teaching in the form of developing their English pedagogics by teaching and focusing on the basics of English. This idea of basics facilitated their English teaching activity and helped them to learn to teach English. Thus basics, according to the participants, referred to knowing how to write capital and small ABCs, remembering spellings of words, knowing how to pronounce words as being able to read fluently, knowing the vocabulary of common use, writing English neatly, and being able to converse and greet at a basic level. They believed that these fundamentals must be taught in the primary grades as students could not suffer in their later grades.

\section{"It seemed like he was the theory and we were the practical."}

This theme refers to student-centered pedagogies that the participant's favorite teachers employed for teaching English. In response to the researcher's question about what was the teaching style/method of his English language teachers he liked and how they engaged him and his friends when they were students, Hadi uttered the above words. The researcher's probing of the words suggested that his teachers' style of teaching English was very practical, easy, moving, charming, and student-centered and friendly. His teacher, being the theory, suggesting that the abstract knowledge about learning a language that the 
teacher had and the students, being practical, suggesting engaging students on part of the teacher in meaningful practice implied the fundamental link that Hadi - now an English teacher himself - believed should exist between English teaching style and engaging students in various learning activities. For example, Hadi stated how his teachers did this:

Unlike the teachers who came in class, asked us to read lessons, asked us meaning and the spelling of words, and gave us new lessons and finished their periods; these teachers [Sir Sarmad and Sir Ahemd] brought students forward before other students and made us act in English, role play in English, and, have conversations in English. They involved us; created opportunities for us to speak in English and learn English. They themselves role-played with us like our class-fellows; they acted like our class-fellows; we enjoyed their teaching so much that we wanted that these teachers teach us English whole day and that the day should not end. We enjoyed and loved them a lot. Unlike other teachers, they did not sit in the class. They more focused upon us and wanted us to practice. They taught us English in ways that we not only enjoyed but we also learned English easily.

Hadi shows the English pedagogies that his favorite teachers adopted for teaching English. The pedagogies were highly student-centered. They provided the students with opportunities of involvement. The students role-played and participated in various activities. Because the students were involved, they enjoyed learning English with the teachers to the point that they wished the teachers would teach for the entire school day. How Hadi taught English, his teaching experiences exhibited the similar pattern. He, for instance, stated:

In fact, I am not a singer, but if these poems [the poems from the textbook] sometimes fit to a certain musical pattern - the musical pattern either I happen to have instantly in my mind during the class or the pattern which resembles to any Sindhi or Urdu song - I try to sing these poems to the children. It creates a lot of fun in the class. Everyone enjoys and listens to me attentively. This is how we read these poems. After I first sing, the students also sing the poems later. If the poems are simple and they can be sung, I sing them and children enjoy the lessons.

This view shows how Hadi adopts a student-centered pedagogy that creates amusement along with learning. He amuses students by converting poems into songs. Although he is not a singer, he puts on the hat of a singer and acts accordingly to make English poems fun, comprehensible, and student-friendly. The students are also involved with this.

This pattern of using student-centered pedagogies and their relation with the pedagogies the participants of this study experienced when their teachers taught them is evident in the other two teachers' data too. For instance, Zamman mentioned the qualities of his favorite teacher, Sir Sarwar. He stated:

There were many qualities in Sir Sarwar's teaching English. For instance, the most important of all was his teaching method. It was very easy, student-oriented, and 
charming. Whatever he taught, he explained things very well in ways that we understood what he discussed. Always involved us and came to our level..... He taught us how to read and write; he taught us vocabulary, their pronunciation, and the use of the words. Most of all, his English pronunciation was very charming and comprehensible.

Zamman mentions the pedagogic qualities that he liked in Sir Sarwar. Sir Sarwar adopted student-centered pedagogies. He not only adapted his teaching to the level of his students but also inspired them to learn English through his pronunciation. Zamman's journal presents a comparable attempt of teaching English. For instance, a piece from his dairy reads:

Today, I had to teach a lesson that was based upon a dialogue. I asked all of students to read the title of the lesson carefully and see the pictures and then tell me what was going on in the lesson. Rather than I tell them, I wanted them to tell me. I asked one of the students from the class to come and ask the meaning of the difficult words from other students. Some guessed incorrectly and some correctly. I had the plans to make the dialogues role-play; but I thought to do it later. Since knowing the spellings of words is an important aspect of learning English vocabulary, I first divided the class into two groups and arranged a spelling contest between them. Total ten words were asked from each team. The group which made more mistakes lost. Thus, one group won. We all had fun.

This snapshot shows how Zamman is adopting a student-centered pedagogy in his class by involving students. His involvement in the process of teaching English vocabulary is evident in every phase from the point of starting the lesson to the point of conducting a spelling competition. The snapshot of teacher-student involvement displays the critical connection of co-constructing knowledge between teachers being theory and students being practical. To conclude, one may argue that from the Vygotskian perspective, the teaching style of the English teachers the participants liked dynamically mediated their activity of English language teaching. It helped them to learn to teach English. It, thus, helped to construct and negotiate their English teacher identities accordingly (Johnson, 2006; 2009; Wertsch, 1985).

\section{Discussion}

The study aimed to understand how the Pakistani primary school teachers learned to teach English in Grades 1 to 5 in the rural areas of the province of Sindh. In particular, it explored how the English language learning experiences of these primary school teachers guided them to conduct their activity of teaching English as per their local conditions. The study found that the teachers taught English, not in the ways they were taught by every teacher, but that they taught English in the ways they liked learning English with some teachers when they were students. The analysis showed there was a pivotal role of the positive apprenticeship of observation that guided and taught them to teach English in a certain way (Johnson, 2006; 2009; Wertsch, 1985). Conducting their teaching activity, thus enacting their identity of the English language teachers at the primary schools, was actively formed by the meditation of their positive language learning experiences that comprised (a) 
the English teachers they adored, (b) the basic concepts of English they developed while they first started learning English, and (c) the student-centered pedagogies that amused them facilitated their activity of English language teaching (Vygotsky, 1987; 1978).

Unlike Lortie (1975) and Westrick and Morris (2016) who take apprenticeship of observation as conservative suggesting that it only consists of negative or partial cognition about teaching, this study finds that the apprenticeship of observation can also include positive or progressive teaching models. Therefore, rather than throwing the baby out with the bathwater, this study contends that the concept should also be taken positively. This study is, thus, in line with Smagorinsy and Barnes (2014) who too problematized the concept and held that it required revision. Discussing what they found in their study with reference to the concept (p. 30), they stated:

...we find that these assumptions are problematic. In contrast to describing their teachers as exclusively authoritarian, the teachers in our study named a variety of teaching models from both the conservative and progressive pedagogical traditions, reflecting on and critiquing teachers from their past and projecting visions of their own teaching according to largely constructivist principles (p. 30).

Smagorinsky and Barnes (2014) argued that their participants not only used the negative impact of their teachers but also the positive ones along with the vision for conducting a progressive style teaching in the future. Their findings resonate with this study. For example, Zamman likes Sir Sarwar but does not like Sirs Nisar Khan and Marghoob. He, thus, does not draw upon the pedagogies that Sirs Nisar Khan and Marghoob used. He, rather, appears agentively adopting the teaching qualities that Sir Sarwar had.

Hadi and Nazakat also stand with him on these lines. Hadi's and Nazakat's journal snapshots demonstrate how their teachers impact them when they teach English in terms of arranging the role-playing activities and competitions for involving students. The data show that Nazakat, Zamman, and Hadi are thoughtful beings. They make a conscious choice between choosing those learning experiences that they cherish and those they do not. One may argue that their choice is not a linear and passive transmission. It is, rather, a conscious effort on the part of the teachers to remember what they liked when they were students and keep their students in mind when they regulate their activity of teaching English as per their students' needs. Additionally, one can contend that Lortie's apprenticeship of observation stands justified here in the sense that the teachers' learning experiences did impact their teaching experiences. In fact, one may not deny the claim. The apprenticeship of observation is indeed existent. However, Lortie only focused upon a partial aspect by his conceptualization and held that it invariably is negative. This study, like Smagorinsky and Barnes (2014), argues that the concept needs reexamination as it could also account for the positive, agentive, and progressive aspects of teaching experiences.

This study also corroborates what Schempp (1987) has discussed and validates what Moodie (2016) has found in South Korea - a similar context to that of Pakistan. Moodie held that anti-apprenticeship of observation influenced the participants' beliefs and teaching practices. She stated that "there was near consensus that prior language learning influenced participants' teaching by motivating them to do something different than what they experienced as students; that is, their prior learning served as an anti-apprenticeship of observation" (p. 38). Moodie held that negative learning experiences engendered intentions 
in her participants to teach differently. Thus, her participants had opposite beliefs about teaching what they had experienced as learners. Moodie (2016), like this study, believes that the apprenticeship of observation exists. However, it does not impact the teachers as Lortie (1975) conservatively conceptualized. All three participants - Nazakat, Hadi, and Zamman - show that they learned to teach English by agentively drawing upon their favorite learning experiences, not the ones that they disliked. When it comes to teaching basics, for instance, they only choose those experiences of learning English as their models of teaching English that they revered and appreciated. Thus, progressive learning experiences seem to be forming their English language teacher identities.

This study shows that the participants are more agentive and reflective practitioners and transformative intellectuals than mere passive technicians as per Kumaravadivelu (2003). Kumaravadivelu (2003) theorized the roles of a teacher in three types: passive technician, who passively transmit knowledge without questioning and adaptation; reflective practitioners, who reflect, exercise their agency, and adapt the knowledge as per their situations; and, transformative intellectuals, who understand that they have to transform and empower not only themselves but also others in order to make their society just and inclusive. It must be mentioned that the participants of this study started learning English from Grade 6 onwards when they were students. However, because of the recent curricular changes, they have been mandated to teach English from Grade 1 onwards. Thus, the textbooks are not the ones they studied. But, because they liked their favorite teachers' pedagogies, they creatively tried to use the pedagogic procedures of their favorite teachers such as engaging students, involving them in learning and teaching English in a fun way. Thus, the participants of the study drew upon their lived experiences in an ingeniously reflective manner when they conducted the activity of teaching. If a lesson was about a lunch dialogue, Nazakat arranged such role-playing activities in his class in order to teach English in a fascinating manner as he was taught. Similarly, Hadi became a singer when he was supposed to teach poems from a textbook. Like Nazakat and Hadi, Zamman also arranged role-playing activities and contests in his class as students could learn English in an unforgettable manner. All these three teachers not only consciously reflected on their learning experiences but also agentively and innovatively utilized the principles of their beloved experiences to transform their students' experiences of learning English.

\section{Conclusion}

Overall, the study shows that there was a macro pattern that the teachers' English language teaching experiences bore a heavy impact of their English language learning experiences. The data demonstrated that teachers taught English, not in ways they were taught, but that they rather agentively taught English in the ways they liked learning English when they were students. The data illustrated that there was a pivotal role of the positive apprenticeship of observation as mediational means that guided and taught to the teachers to teach English in a certain way.

Like any research, this study also has certain limitations that the researcher wants readers to keep in mind while interpreting the findings. First, Nazakat was the first participant that the researcher contacted because the researcher knew him as an active and committed teacher. Hadi and Zamman were the suggestions that Nazakat offered to the 
researcher. These both were also dynamic teachers. Assuming that all the government primary school teachers in Sindh, Pakistan would be self-motivated and vibrant as these three teachers appeared may not be appropriate. Thus, supposing English is taught in the government primary schools of Sindh, Pakistan the way these three taught English cannot be generalized. Secondly, in whatever manner these three teachers taught, we cannot know if they were successful or better than other teachers. Therefore, it must also be looked into whether these teachers were better or successful teachers by including in future studies their colleagues' and students' perspectives and/or their scores on the English subject. Thirdly, whether their teacher education credentials impacted the way they taught English was not directly examined. This study implies that it must be studied in order to more precisely understand the apprenticeship of observation phenomenon. Fourth, all three participants of this study were males. Thus, findings must be interpreted as such. Whether female teachers also act the same as the male ones did in this study is unknown. Fifth, each of these three teachers belonged to the rural areas of the province of Sindh and government primary schools. Thus, urban teachers and the teachers who teach in Sindh at secondary level Grade 6 to 10 - or at the college level - Grades 11 to 12 -also need to be studied to systematically comprehend the phenomenon in question. In sum, it must be kept in mind that this study involved only three rural male government primary school teachers who wrote their diaries as per their ease and that the researcher interviewed them through Skype.

Despite these limitations, the study has worthwhile suggestions. The study invites scholars working on how teachers learn to teach to thoroughly study the apprenticeship of observation and rethink the phenomenon on sociocultural theoretical lines. Doing this would help scholars to bring forth progressive aspects of teachers' lived experiences. In the same vein, the study implies that Pakistani teacher education policymakers, curriculum designers, and teacher trainers need to be sensitized to view teachers as socio-cultural beings whose knowledge development is invariably contextual (Johnson, 2009; Johnson \& Golombek, 2016). By viewing teachers as sociocultural beings, these stakeholders can build upon the comprehensive professionalism model that Rizvi and Elliot $(2005 ; 2007)$, for instance, have proposed for developing teachers as dynamic professionals. The authorities can be sensitized to appreciate the agentive role that teachers' progressive lived experiences could play in shaping their identity and teaching them to teach a subject in a reflective way (Borg, 2006, 2009; Schön, 1983, 1987 and Zeichner \& Liston, 1996).

Correspondence should be addressed to: Liaquat Ali Channa.

Email: channaliaquat@yahoo.com

\section{References}

Allwright, D., \& Bailey, K. (1994). Focus on the language classroom: An introduction to classroom research for language teachers. New York: Cambridge University Press.

Channa, L. A. (2014). English medium for government primary school teachers of Sindh, Pakistan: An exploration of government primary school teachers' attitudes (Unpublished doctoral dissertation). University of Georgia, Georgia, USA.

Channa, L. A. (2015). English in the language policy and planning of Pakistan. Kashmir Journal of Language Research, 18, 65-77. 
Channa, L. A., \& Manan, S. A. (2015). Developing Pakistani university students' English proficiency: A five-point agenda for the Pakistani language policymakers. BUITEMS Journal of Social Sciences and Humanities 1(2), 89-101.

Channa, L. A. (2017). English in Pakistani public education: Past, present, and future. Language Problems \& Language Planning, 41(1), 1-25. doi:10.1075/1plp.41.1.01cha

Channa, L. A. \& Panezai, S. G. (2019). Top-down English policy and bottom-up teacher take: An interview-based insight from the Balochistan province of Pakistan. The Qualitative Report, 24(9), 2281-2296. Retrieved from https://nsuworks.nova.edu/tqr/vol24/iss9/13

Bashiruddin, A. (2003). Learning English and learning to teach English: The case for two teachers of English in Pakistan (Unpublished doctoral dissertation), Ontario Institute for Studies in Education, University of Toronto, Canada.

Borg, M. (2004). The apprenticeship of observation. ELT Journal, 58(3), 274-276.

Borg, S. (2006). Teacher cognition and language education: Research and practice. New York, NY: Continuum.

Borg, S. (2009). Language teacher cognition. In A. Burns, \& J. C. Richards (Eds.), The Cambridge guide to second language teacher education (pp. 163-171). New York, NY: Cambridge University Press.

Boyd, A., Gorham, J. J., Justice, J. E., \& Anderson, J. L. (2013). Examining the apprenticeship of observation with pre-service teachers: The practice of blogging to facilitate autobiographical reflection and critique. Teacher Education Quarterly, 40(3), 27-49.

Braun, V., \& Clarke, V. (2006). Using thematic analysis in psychology. Qualitative Research in Psychology, 3(2), 77-101.

Bullock, S. M. (2011). Inside teacher education: Challenging prior views of teaching and learning. New York: Sense Publishers.

Chaudron, C. (1988). Second language classrooms: Research on teaching and learning. New York: Cambridge University Press.

Cohen, L., Manion, L., \& Morrison, K. (2007). Research methods in education. New York: Routledge.

Cole, H. (2010). Teaching and learning in Pakistan: The role of language in education. Islamabad: The British Council.

Darling-Hammond, L. (2006). Constructing $21^{\text {st }}$-century teachers education. Journal of Teacher Education, 57(3), 300-314.

Greenwalt, K. A. (2014). Frustrated returns: Biography, parental Figures, and the apprenticeship of observation. Curriculum Inquiry, 44(3), 306-331.

Haider, I. (2015). Supreme court order govt to adopt Urdu as official language. Retrieved from https://www.dawn.com/news/1205686

Halai, N. (2007). Making use of bilingual interview data: Some experiences from the field. The Qualitative Report, 12(3), 344-355.

Johnson, K. E. (2006). The sociocultural turn and its challenges for second language teacher education. TESOL Quarterly,40(1), 235-257.

Johnson, K. E. (2009). Second language teacher education: A sociocultural perspective. New York: Routledge.

Johnson, K. E. \& Golombek, P. R. (2016). Mindful L2 teacher education: A sociocultural perspective on cultivating teachers ' professional development. New York: Routledge. 
Knapp, N. F. (2012) Reflective journals: Making constructive use of the "apprenticeship of observation" in preservice teacher education. Teaching Education, 23(3), 323-340.

Kumaravadivelu, B. (2003). Beyond methods: Macrostrategies for language teaching. Yale: Yale University Press.

Lantolf, J. P., and Poehner, M. E. (Eds.). (2008). Sociocultural theory and the teaching of second languages. Oakville: Equinox.

Lantolf, J. P., and Thorne, S. L. (2007). Sociocultural theory and second language learning. In B. VanPatten and J. Williams (Eds.). Theories in second language acquisition: An introduction (pp. 201-224). Mahwah, New Jersey: Lawrence Erlbaum Associates.

Larsen-Freeman, D. (2000). Techniques and principles in language teaching (2 ${ }^{\text {nd }}$ Ed.). New York: Oxford University Press.

Lier, L.V. (1988). The classroom and the language learner. New York: Longman.

Lortie, D. C. (1975). Schoolteacher: A sociological study. Chicago: University of Chicago Press.

Mahboob, A. (2002). No English, no future: Language policy in Pakistan. In S. Obeng \& B. Hartford (eds.). Political Independence with Linguistic Servitude: The Politics about Languages in the Developing World. New York: NOVA Science.

Manan, S. A., David, M. K., \& Dumanig, F. P. (2016). English Language Teaching in Pakistan: Language Policies, Delusions and Solutions. In R. Kirkpatrick (Ed.), English Language Education Policy in Asia (Vol. 11, pp. 219-244): Springer International Publishing.

Mansoor, S. (2004). The status and role of regional languages in higher education in Pakistan. Journal of Multicultural and Multilingual Development, 25(04), 333-353.

Markee, N. (2000). Conversation analysis. Mahwah, NJ: Lawrence Erlbaum.

Mewborn, D. S., \& Tyminski, A. M. (2006). Lortie's apprenticeship of observation revisited. For the Learning of Mathematics, 26(3), 23-32.

Moodie, I. (2016). The anti-apprenticeship of observation: How negative prior learning experiences influences English language teachers' beliefs and practices. System, 60, $29-41$.

Nowell, L. S., Norris, J. M., White, D. E., \& Moules, N. J. (2017). Thematic analysis: Striving to meet the trustworthiness Criteria. International Journal of Qualitative Methods, 16(1).

Panezai, S. G., \& Channa, L. A. (2017). Pakistani government primary school teachers and the English textbooks of Grades 1-5: A mixed-methods teachers'-led evaluation. Cogent Education, 4(1). doi:10.1080/2331186X.2016.1269712

Rahman, T. (1996). Language and politics in Pakistan. Karachi: Oxford University Press.

Rahman, T. (2002). Language, ideology and power: language learning among the Muslims of Pakistan and North India. Karachi: Oxford: Oxford University Press.

Richards, J., \& Rodgers, T. (2001). Approached and methods in language teaching ( $2^{\text {nd }}$ Ed.). Cambridge: Cambridge University Press.

Rizvi, M. \& Elliott, B. (2005). Teachers' perceptions of their professionalism in Government primary schools in Karachi. Pakistan. Asia-Pacific Journal of Teacher Education, 33(1), 35-52.

Rizvi, M. \& Elliott, B. (2007). Enhancing and sustaining teacher professionalism in Pakistan. Teachers and teaching: Theory and practice, 13(1), 5-19.

Roulston, K. (2010). Reflective interviewing: A guide to theory and practice. Los Angles: Sage. 
Schachter, J. \& Gass, S. (Eds.). (1996). Second language classroom research: Issues and opportunities. Mahwah: Lawrence Erlbaum.

Schempp, P. G. (1987, April). A study of Lortie's "apprenticeship-of-observation" theory in physical education. Paper presented at the annual meeting of the American Educational Research Association, Washington, D.C. Retrieved from https://files.eric.ed.gov/fulltext/ED284833.pdf

Schön, D. (1983). The reflective practitioner: How professionals think in action. New York, NY: Basic Books.

Schön, D. (1987). Educating the reflective practitioner: Toward a new design for teaching and learning in the professions. San Francisco, CA: Jossey Bass.

Shenton, A. K. (2004). Strategies for ensuring trustworthiness in qualitative research projects. Education for Information, 22(2). 63-75.

Smagorinsky, P., \& Barnes, M. E. (2014). Revisiting and revising the apprenticeship of observation. Teacher Education Quarterly, 41(4), 29-52.

Stake, R. E. (1995). The art of case study research. Thousand Oaks: Sage.

Thorpe, K. (2004) Reflective learning journals: From concept to practice. Reflective Practice, 5(3), 327-343.

Vygotsky, L. S. (1987). Thinking and speech. In L. S. Vygotsky, Collected works (Vol. 1, pp. 39-285) (R. Rieber \& A. Carton, Eds.; N. Minick, Trans.). New York: Plenum.

Vygotsky, L. S. (1978). Mind in society: The development of higher psychological processes (M. Cole, V. John-Steiner, S. Scribner, \& E. Souberman, Eds.). Cambridge, MA: Harvard University Press.

Wertsch, J. V. (1985). Vygotsky and the social formation of mind. Cambridge, MA: Harvard University Press.

Westrick, J. M., \& Morris, G. A. (2016). Teacher education pedagogy: Disrupting the apprenticeship of observation. Teaching Education, 27(2), 156-172.

Yin, R. K. (2013). Case study research: Design and methods. New York: Sage.

Zeichner, K. M., \& Liston, D. P. (1996). Reflective teaching: An introduction. Mahwah, NJ: Erlbaum. 